\title{
FAKTOR-FAKTOR YANG MEMPENGARUHI KINERJA KARYAWAN OPERATOR PADA PT IKP BOGOR
}

\author{
Sandi Noorzaman dan Putri Pertiwi \\ Sekolah Tinggi Ilmu Ekonomi GICI, Bogor, Indonesia \\ Email: s_noorzaman@yahoo.com
}

\begin{abstract}
This research aims to determine and analyze the influence of motivation, incentives and organizational culture on employee performance at PT IKP-Bogor. Type of this research uses associative quantitative research, the research analysis is multiple linear regression analysis. The results showed simultaneously that the variables of motivation, incentives and organizational culture had a significant effect on employee performance, while partially the variables that had an effect on employee performance were motivation and organizational culture. The results of the coefficient of determination show the variables of motivation, incentives and organizational culture can explain the employee performance variable by $67 \%$, while the remaining $33 \%$ is explained by other variables outside of this research. The implication of this research is that the company is expected to motivate and create an employee-oriented organizational culture.
\end{abstract}

\section{Keywords: Motivation, Incentives, Organizational Culture and Employee Performance}

ABSTRAK

Penelitian ini bertujuan untuk mengetahui dan menganalisa Pengaruh Motivasi, Insentif dan Budaya Organisasi Kinerja Karyawan pada PT IKP-Bogor. Jenis penelitian ini menggunakan penelitian kuantitatif assosiatif, dengan analisis penelitian adalah analisis regresi linier berganda. Hasil penelitian menunjukkan secara simultan bahwa variabel motivasi, insentif dan budaya organisasi berpengaruh signifikan terhadap kinerja karyawan, sedangkan secara parsial variabel yang berpengaruh terhadap kinerja karyawan adalah variabel motivasi dan budaya organisasi. Hasil koefisien determinasi menunjukkan variabel motivasi, insentif dan budaya organisasi dapat menjelaskan terhadap variabel kinerja karyawan sebesar $67 \%$, sedangkan sisanya sebesar 33\% dijelaskan oleh variabel lain diluar penelitian ini. Implikasi dari penelitian ini diharapkan perusahaan dapat memotivasi dan menciptakan budaya organisasi yang berorientasi pada karyawan.

Kata Kunci: Motivasi, Insentif, Budaya Organisasi dan Kinerja Karyawan

\section{KETERANGAN ARTIKEL}

Riwayat Artikel: diterima: 23 April 2020; direvisi: 1 Juni 2020; disetujui: 27 Juni 2020

Klasifikasi JEL: J24

Cara Mensitasi: Noorzaman, S. dan Pertiwi, P. (2020). Faktor-Faktor yang Mempengaruhi Kinerja Karyawan Operator Pada PT IKP Bogor. JIMFE (Jurnal IImiah Manajemen Fakultas Ekonomi), 6(1), 123-134. https://doi.org/10.34203/jimfe.v6i1.1959

Copyright@2020. JIMFE (Jurnal IImiah Manajemen Fakultas Ekonomi) Universitas Pakuan

\section{PENDAHULUAN}

Kinerja karyawan merupakan hasil kerja yang menunjukkan tingkat keberhasilan karyawan dalam melaksanakan tugasnya secara keseluruhan dan sesuai dengan standar yang sudah ditentukan. Di antara faktor-faktor yang diduga memengaruhi kinerja karyawan adalah pemberian motivasi, insentif, dan menciptakan budaya organisasi yang baik. Motivasi karyawan dapat muncul dari dalam diri sendiri sebagai akibat dari adanya keinginan memenuhi kebutuhan atau dapat 
didukung pula oleh kondisi eksternal seperti adanya dukungan spiritual dari orang lain. Hal lain yang mendorong kinerja karyawan menjadi lebih tinggi adalah pemberian insentif sebagai bentuk penghargaan perusahaan pada hasil kerja karyawan. Melalui pemberian insentif, karyawan akan merasa bahwa perusahaan memperhatikan kinerjanya. Perusahaan juga perlu membentuk budaya organisasi yang tepat untuk menyeragamkan persepsi karyawan melalui norma-norma, kebiasaan-kebiasaan, dan batasan-batasan perusahaan sebagai maksud untuk menjaga stabilitas perusahaan, sehingga aktivitas perusahaan akan berjalan dengan baik sesuai dengan standar yang ada.

Dalam kajian ini tak lepas dari yang namanya manusia dan sumber daya itu sendiri. Hanggraeni (2012) mengatakan bahwa manajemen sumber daya manusia berhubungan dengan sebuah organisasi dalam merancang sistem formal yang menjamin pemanfaatan sumber daya manusia secara efektif dan efisien guna mendukung pencapaian tujuan dan rencana strategis organisasi serta tujuan dalam suatu perusahaan.

Walaupun kita tahu bahwa peran manusia dalam berbagai sisi kehidupan adalah mutlak namun peran manusia dalam perusahaan, baru diakui belakangan ini. Kita dapat melihat dari bagaimana pengelolaan manusia dalam suatu perusahaan dijalankan. Melihat keadaan seperti ini, perusahaan harus mampu memperhatikan dan memberikan motivasi kepada karyawannya serta menata ulang kebijakan dalam memenuhi kebutuhan karyawannya agar bisa bekerja dengan lebih baik. Motivasi merupakan dorongan sebab atau alasan seseorang melakukan sesuatu. Dengan demikian motivasi dapat diartikan suatu kondisi yang mendorong atau menjadi sebab seseorang melakukan suatu perbuatan/kegiatan yang berlangsung secara sadar (Destiana et.al, 2015).

Berdasarkan penelitian terdahulu dengan judul kajian yang sama mengenai insentif yang mempengaruhi kinerja karyawan, maka ada beberapa teori mengenai kajian terdahulu yang mampu menguatkan refrensi dalam kajian ini. Adapun pemberian insentif merupakan salah satu hal pokok yang harus diperhatikan oleh perusahaan guna memberikan semangat pada para pekerja serta motivasi bagi mereka agar lebih meningkatkan kinerjanya (Nurani, 2015). Dalam kajian lain diterangkan bahwa salah satu cara mengoptimalkan kinerja karyawan adalah dengan pemberian balas jasa (insentif) secara tidak sengaja diberikan kepada karyawan agar di dalam diri mereka timbul semangat yang lebih besar untuk meningkatkan prestasi kerja sehingga produktivitas dan kinerjanya meningkat (Maziah, 2017). Berbagai penelitian juga telah dilakukan sebagaimana Mustofa (2017) menunjukkan bahwa insentif berpengaruh signifikan terhadap kinerja karyawan adalah benar dan dapat diterima. Dalam kajian analisis lainnya Haedar, dkk. (2015) juga menunjukkan insentif berpengaruh secara signifikan terhadap kinerja karyawan.

Kinerja karyawan yang terdapat di Indonesia lebih berpotensi dari negara lain di Asia (Watson, 2005). Budaya memiliki pengaruh penting dalam perkembangan dunia bisnis di Indonesia karena keanekaragaaman budaya yang ada. Budaya membedakan masyarakat satu dengan yang lain dalam cara berinteraksi dan bertindak menyelesaikan suatu pekerjaan. Budaya mengikat anggota kelompok masyarakat menjadi satu kesatuan pandangan yang menciptakan keseragaman berperilaku atau bertindak. Budaya juga memiliki pengaruh penting dalam perkembangan dunia bisnis di Indonesia (Hutomo, dkk., 2015).

Berdasarkan data yang diperoleh, hasil produksi PT IKP Tahun 2017 mengalami fluktuasi yang bergantung pada jumlah permintaan customer (pelanggan). Karyawan dituntut untuk mencapai $100 \%$ target produksi di setiap bulannya, tetapi produksi yang memenuhi bahkan melebihi target hingga 
101\% dengan angka produk NG (Not Good) $0,2 \%$ hanya terjadi di bulan Desember yang justru memiliki target paling rendah dari bulan-bulan sebelumnya. Bulan JanuariNovember karyawan hanya menghasilkan $94 \%$ - 99\% dari target produksi dengan produk NG 0,3\%-0,4\%. Rata-rata produksi 2017 hanya tercapai $97 \%$ dengan rata-rata produk NG $0,3 \%$. Hal ini berarti kinerja karyawan dapat dikatakan cukup stabil tetapi karyawan harus lebih efektif dalam memenuhi target serta diperlukan upaya maksimal untuk meningkatkan efisiensi biaya dengan mengurangi jumlah produk NG setiap bulannya.

Pada penelitian Maria, dkk. (2016) menghitung dua variabel dengan metode yang sama yaitu menggunakan analisi regresi linear berganda. Adapun pembaruan dalam penelitian ini ialah menggunakan tiga variabel dengan metode penelitian yang sama berupa analisis regresi linear berganda.

\section{KAJIAN LITERATUR DAN PENGEMBANGAN HIPOTESIS}

\section{Manajemen Sumber Daya Manusia}

Manajemen sumber daya manusia adalah kebijakan dan praktik dalam menentukan aspek manusia itu sendiri dalam memposisikannya di suatu perusahaan atau organisasi. Tujuan manajemen sumber daya manusia secara umum adalah untuk memastikan bahwa organisasi atau perusahaan mampu mencapai keberhasilan melalui orang tersebut. Sistem manajemen sumber daya manusia dapat menjadi sumber kapabilitas organisasi yang memungkinkan perusahaan atau organisasi dapat belajar dan mempergunakan kesempatan untuk hal baru (Sedarmayanti, 2015).

Perubahan era yang semakin maju, mendorong manusia ingin mencapai kehidupan yang lebih baik. Pencapaian tersebut ditunjukan melalui kinerja dan prestasi yang diberikan dalam bekerja, sehingga dibutuhkan kemampuan atau kinerja dari karyawan yang lebih baik. Jika kinerja mereka kurang baik, maka dalam memajukan perusahaan pun akan dipastikan tidak baik. Sementara itu di lain pihak, perusahaan turut campur tangan dalam membantu karyawan mencapai kehidupan mereka khususnya untuk mencukupi kebutuhan mereka sehari-hari. Salah satunya adalah merekrut para calon karyawan untuk bekerja di perusahaan. Tentunya perusahaan mengeluarkan uang untuk membayar upah para karyawan agar bisa mendapatkan karyawan atau sumber daya manusia (SDM) yang berkualitas, baik dalam sifat maupun kinerja. Pada dasarnya setiap Instansi pemerintah maupun swasta, bukan saja mencari karyawan yang mampu cakap dan terampil, tetapi yang terpenting mereka mau bekerja giat dan berkeinginan mencapai hasil kerja yang optimal (Theodora, 2015).

Sumber Daya Manusia (SDM) seringkali dikaitkan dengan kepegawaian, karyawan, atau tenaga kerja yang menjadi penggerak suatu organisasi. Zainal, dkk. (2015) berpendapat bahwa SDM adalah seseorang yang siap, mau, dan mampu memberi sumbangan terhadap usaha pencapaian tujuan organisasi. Adapun dalam bagian sumber daya manusia ini tentu harus memiliki perencanaan bagi sumber daya tersebut agar pemanfaatan dan tujuan dalam suatu organisasi atau pekerjaan tercapai, maka perencanaan dalam menempatkan dan meletakkan sumber daya itu sesuai dengan porsi dan bagiannya tentu sangat berpengaruh. Semuanya itu untuk mencapai tujuan dan sasaran masing-masing sesuai dengan yang sudah ditetapkan. (Siagian, 2015).

Berbeda dengan Manajemen Sumber Daya Manusia (MSDM) yang biasanya dikaitkan dengan rangkaian kegiatan, mulai dari pengadaan hingga pengelolaan sumber daya manusia yang menjadi penggerak suatu organisasi. Istilah "manajemen" mempunyai arti sebagai kumpulan pengetahuan tentang bagaimana seharusnya mengelola sumber daya manusia (Zainal dkk., 2015). 


\section{Motivasi}

Motivasi mengacu pada proses dimana usaha seseorang diberi energi, diarahkan dan berkelanjutan menuju tercapainya suatu tujuan (Robbins \& Mary, 2016). Teori Maslow yang menyatakan bahwa dalam setiap orang terdapat sebuah hierarki dari lima kebutuhan yang disebut kebutuhan fisiologis (physiological needs), yaitu kebutuhan akan makanan, minuman, tempat berteduh, seks dan kebutuhan fisik lainnya, kebutuhan keamanan (safety needs): kebutuhan akan keamanan dan perlindungan dari kejahatan fisik dan emosional, serta jaminan bahwa kebutuhan fisik akan terus terpenuhi, kebutuhan sosial (social needs): kebutuhan akan kasih sayang, rasa memiliki, penerimaan dan persahabatan, kebutuhan penghargaan (esteem needs): kebutuhan akan faktor-faktor penghargaan internal, seperti harga diri, otonomi dan prestasi, serta faktor-faktor penghargaan eksternal, seperti status, pengakuan, perhatian dan kebutuhan aktualisasi-diri (self-actualization needs): kebutuhan akan pertumbuhan, pencapaian potensi seseorang dan pemenuhan diri, dorongan untuk mampu menjadi apa yang diinginkan.

Motivasi adalah keinginan dalam diri seseorang yang menyebabkan orang tersebut bertindak. Biasanya orang bertindak karena suatu alasan untuk mencapai tujuan. Memahami motivasi sangatlah penting karena kinerja, reaksi terhadap kompensasi dan persoalan sumber daya manusia yang lain dipengaruhi dan mempengaruhi motivasi. Pendekatan untuk memahami motivasi berbeda-beda, karena teori yang berbeda mengembangkan pandangan dan model mereka sendiri (Gardjito dkk., 2014).

\section{Insentif}

Zainal, dkk. (2015) berpendapat bahwa insentif diartikan sebagai bentuk pembayaran yang dikaitkan dengan kinerja dan gain sharing, sebagai pembagian keuntungan bagi karyawan akibat peningkatan produktivitas atau penghematan biaya. Badriyah (2017) menjelaskan agar insentif bisa berhasil, perlu diperhatikan yaitu pembayaran hendaknya sederhana agar dapat dimengerti dan dihitung oleh pegawai sendiri, penghasilan yang diterima buruh hendaknya langsung menaikkan output dan efisiensi, pembayaran hendaknya dilakukan secepat mungkin, standar kerja hendaknya ditentukan dengan hati-hati, standar kerja yang tinggi ataupun terlalu rendah sama tidak baiknya dan besarnya upah normal dengan standar kerja per-jam hendaknya cukup merangsang pekerja untuk bekerja lebih giat.

Hatta dan Habibi (2018) menyatakan bahwa tujuan pemberian insentif adalah untuk meningkatkan produktivitas kerja karyawan serta mempertahankan karyawan yang berprestasi agar tetap bekerja di perusahaan tersebut. Insentif dapat menjadi motivator bagi karyawan perusahaan agar lebih bersemangat dalam bekerja, sehingga dapat meningkatkan kinerja. Beberapa sifat dasar insentif yang harus dipenuhi agar sistem upah dapat berhasil yaitu pembayarannya hendaknya sederhana, sehingga dapat dimengerti dan dihitung oleh karyawan sendiri; penghasilan yang diterima oleh karyawan hendaknya langsung menaikkan output dan efisiensi; pembayarannya hendaknya dilakukan secepat mungkin; standar kerja hendaknya ditentukan dengan hati- hati karena standar kerja yang terlalu tinggi atau terlalu rendah sama tidak baiknya; besarnya upah normal dengan standar kerja per jam hendaknya cukup merangsang pekerja untuk bekerja lebih giat. Insentif merupakan suatu pendorong untuk melakukan tindakan pencapaian tujuan.

\section{Budaya Organisasi}

Setiap individu selalu mempunyai sifat yang berbeda satu dengan yang lainnya. Sifat tersebut dapat menjadi ciri khas bagi seseorang, sehingga kita dapat mengetahui bagaimana sifatnya. Sama halnya dengan manusia, organisasi juga mempunyai sifat-sifat 
tertentu. Melalui sifat-sifat tersebut kita juga dapat mengetahui bagaimana karakter dari organisasi tersebut. Sifat tersebut kita kenal dengan budaya organisasi atau organization culture (Nouziransyah, 2017).

Robbins dan Mary (2016) menyatakan bahwa budaya organisasi sebagai himpunan nilai, prinsip, tradisi dan cara bekerja yang dianut bersama oleh para anggota organisasi dan memengaruhi cara mereka bertindak serta membedakan organisasi tersebut dengan organisasi lainnya. Terdapat tujuh dimensi yang menjabarkan budaya suatu organisasi, yaitu: inovasi dan pengambilan risiko, perhatian pada detail, orientasi hasil, orientasi manusia, orientasi tim, agresivitas, dan stabilitas.

Adanya hubungan antara budaya organisasi dengan kinerja karyawan atau anggota organisasi dapat tercermin dalam perilaku organisasi tersebut. Saat karyawan meniru perilaku yang sesusai dengan budaya organisasinya maka akan ada kepuasan tersendiri dan bahkan ada imbalan secara langsung atau tidak langsung. Budaya organisasi menjadi suatu pedoman perilaku bagi anggotanya yang secara tidak sadar diterapkan dalam menjalankan kegiatannya (Wardani, dkk., 2016).

\section{Kinerja Karyawan}

Salah satu faktor yang mendorong peningkatan kinerja adalah lingkungan kerja yang menyenangkan. Pada dasarnya penilaian kinerja ini merupakan proses pengamatan terhadap pelaksanaan pekerjaan oleh karyawan. Adapun tujuan dilakukannya penilaian kinerja adalah untuk meningkatkan kemampuan karyawan, mengidentifikasi faktor penghambat dan penetapan kebijakan strategis (Fatimah, 2017).

Kinerja (performance) adalah hasil pekerjaan yang dicapai seseorang berdasarkan persyaratan-persyaratan pekerjaan (job requirement). Suatu pekerjaan mempunyai persyaratan tertentu untuk dapat dilakukan dalam mencapai tujuan yang disebut juga sebagai standar pekerjaan (job standard) (Bangun, 2012). Suatu pekerjaan dapat diukur melalui jumlah pekerjaan, kualitas pekerjaan, ketepatan waktu, kehadiran, dan kemampuan kerja sama.

\section{Hipotesis}

H1: Motivasi, insentif dan budaya organisasi berpengaruh secara bersama-sama terhadap kinerja karyawan operator PT IKP

H2: Motivasi berpengaruh terhadap kinerja karyawan operator PT IKP

H3: insentif berpengaruh terhadap kinerja karyawan operator PT IKP

H4: budaya organisasi berpengaruh terhadap kinerja karyawan operator PT IKP

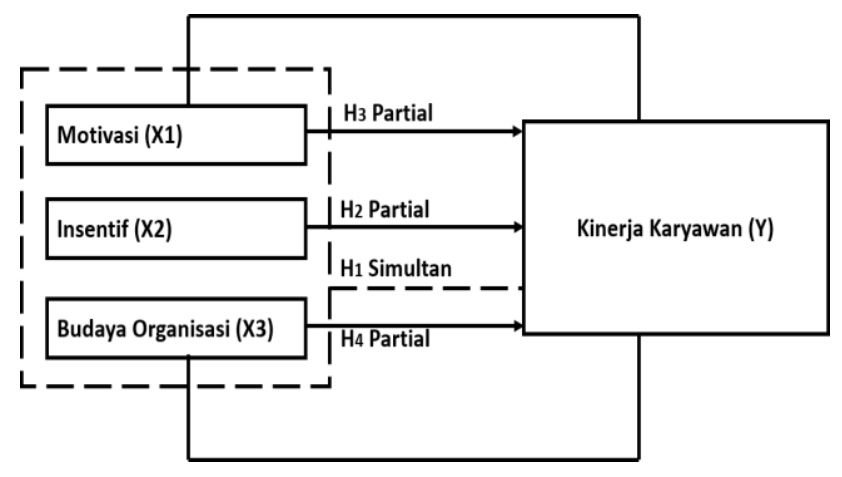

Gambar 1. Kerangka Konseptual

\section{METODE PENELITIAN}

Metode yang digunakan dalam kajian ini dalam pengukuran datanya adalah metode kuantitatif, dimana metode kuantitatif menurut Dr.Sugiyono ialah metode scientific karena telah memenuhi kaidah ilmiah yaitu terukur, empiris, obyektif, rasional, dan sistematis. Metode kuantitatif dapat diartikan sebagai metode penilitian yang berlandaskan pada filsafat positivisme, digunakan untuk meneliti populasi atau sampel, pengumpulan data menggunakan instrumen penelitian, analisis data bersifat kuantitatif dengan tujuan menguji hipotesis yang telah ditetapkan. (Sugiyono, 2018). 
Sandi Noorzaman: Faktor-faktor yang Mempengaruhi ...

\section{Populasi dan Sampel}

Populasi dalam penelitian ini adalah seluruh karyawan operator produksi pada divisi Plant satu dan dua di departemen Production dua dan Quality Assurance PT IKP-Bogor yang berjumlah 167 karyawan. Sampel yang diperoleh dengan purpossive sampling sebanyak 51 karyawan dengan pertimbangan dan ketentuan hanya karyawan operator produksi bagian finishing dan laboratorium atau checking, hanya karyawan operator produksi yang bekerja di shift pagi atau nonshift dan karyawan yang ada dalam waktu longgar (tidak sedang melakukan pekerjaan).

\section{Operasionalisasi Variabel}

Indikator yang digunakan untuk variabel motivasi adalah kebutuhan fisiologis, kebutuhan keamanan, kebutuhan sosial, kebutuhan penghargaan dan kebutuhan aktualisasi diri. Adapun indikator untuk variabel isentif adalah pembayaran hendaknya sederhana, dapat menaikkan output dan efisiensi, pembayaran dilakukan secepat mungkin, standar kerja mudah diikuti dan mampu menstimulasi semangat kerja.

Indikator untuk variabel budaya organisasi adalah terdiri dari budaya organisasi yaitu inovasi dan pengambilan risiko, perhatian pada detail, orientasi hasil, orientasi manusia, orientasi tim, agresivitas dan stabilitas. Adapun indikator untuk variabel kinerja karyawan yaitu jumlah pekerjaan dan kualitas pekerjaan yang dikerjakan.

\section{Teknik Analisis Data dan Uji Hipotesis}

Analisis data penelitian ini menggunakan analisis regresi linier berganda, yaitu analisa yang dilakukukan untuk melihat pengaruh variabel independen baik secara simultan maupun parsial. Adapun uji yang dilakukan adalah uji statistik $t$ pada dasarnya menunjukan seberapa signfikan pengaruh suatu variabel penjelas atau independen secara individual dalam menerangkan variasi dependen. Uji F dilakukan untuk menunjukkan seberapa besar signifikan seluruh variabel terhadap variabel dependennya secara simultan. Uji Koefesien Determinasi $\left(R^{2}\right)$, pada intinya mengukur seberapa jauh kemampuan variabel bebas dapat menjelaskan beberapa variasi variabel terikat.

\section{HASIL DAN PEMBAHASAN \\ Deskripsi Objek Penelitian}

PT IKP berdomisili di Kabupaten Bogor, merupakan suatu perusahaan perseroan terbatas yang bergerak dalam usaha industri sepeda motor, suku cadang dan aksesori kendaraan bermotor roda dua dengan jenis barang komponen kendaraan dari karet roda dua. Adapun quality, safety, health, dan environment system PT IKP menggunakan ISO 9001:2008, ISO/TS 16949:2009, ISO 14001:2004, dan BS OHSAS 18001:2017

\section{Deskripsi Data Responden}

Responden dalam penelitian ini didominasi oleh laki-laki sebanyak 76,5\%, karyawan dengan usia < 31 tahun sebanyak 43,10\%, karyawan dengan pendidikan terakhir SMA/K sebanyak $86,3 \%$, karyawan dengan masa kerja $<11$ tahun sebanyak 49\% dan karyawan yang sudah menikah sebanyak $86,3 \%$. Data yang digunakan adalah data primer yaitu hasil dari penyebaran kuesioner kepada responden. Data sekunder diperoleh melalui data perusahaan, buku dan literatur lainnya.

\section{Uji Validitas dan Uji Reliabilitas}

Uji validitas dilakukan pada setiap butir pertanyaan pada kuesioner tertera pada Tabel 1 sampai dengan Tabel 4 untuk masing-masing variabel. Hasil $r$ hitung dibandingkan dengan $r$ tabel dimana $\mathrm{df}=\mathrm{n}-2$ dengan sig $5 \%$. Jika $r$ tabel $<$ r hitung maka valid (Sujarweni, 2015). 
JIMFE (Jurnal Ilmiah Manajemen Fakultas Ekonomi) https://journal.unpak.ac.id/index.php/jimfe

Tabel 1. Hasil Uji Validitas $X_{1}$ Motivasi

\begin{tabular}{cccc} 
No. & $\mathbf{r}_{\text {hitung }}$ & $\mathbf{r}_{\text {tabel }}$ & Ket \\
\hline X1.1 & 0,374 & 0,2759 & Valid \\
\hline X1.2 & 0,621 & 0,2759 & Valid \\
\hline X1.3 & 0,619 & 0,2759 & Valid \\
\hline X1.4 & 0,644 & 0,2759 & Valid \\
\hline X1.5 & 0,626 & 0,2759 & Valid \\
\hline X1.6 & 0,589 & 0,2759 & Valid \\
\hline X1.7 & 0,577 & 0,2759 & Valid \\
\hline X1.8 & 0,748 & 0,2759 & Valid \\
\hline X1.9 & 0,493 & 0,2759 & Valid \\
\hline X1.10 & 0,662 & 0,2759 & Valid \\
\hline
\end{tabular}

Tabel 2. Hasil Uji Validitas $X_{2}$ Insentif

\begin{tabular}{cccc}
$\mathbf{N o}$ & $\mathbf{r}_{\text {hitung }}$ & $\mathbf{r}_{\text {tabel }}$ & Ket \\
\hline $\mathrm{X} 2.1$ & 0,654 & 0,2759 & Valid \\
\hline $\mathrm{X} 2.2$ & 0,482 & 0,2759 & Valid \\
\hline $\mathrm{X} 2.3$ & 0,723 & 0,2759 & Valid \\
\hline $\mathrm{X} 2.4$ & 0,664 & 0,2759 & Valid \\
\hline $\mathrm{X} 2.5$ & 0,692 & 0,2759 & Valid \\
\hline $\mathrm{X} 2.6$ & 0,732 & 0,2759 & Valid \\
\hline $\mathrm{X} 2.7$ & 0,423 & 0,2759 & Valid \\
\hline $\mathrm{X} 2.8$ & 0,757 & 0,2759 & Valid \\
\hline $\mathrm{X} 2.9$ & 0,342 & 0,2759 & Valid \\
\hline
\end{tabular}

Vol. 6 No. 1, Juni 2020, Hal. 123-134 P-ISSN: 2502-1400, E-ISSN: 2502-5678
Tabel 3. Hasil Uji Validitas $\mathrm{X}_{3}$ Budaya Organisasi

\begin{tabular}{cccc} 
No. & $\mathbf{r}_{\text {hitung }}$ & $\mathbf{r}_{\text {tabel }}$ & Ket \\
\hline X3.1 & 0,375 & 0,2759 & Valid \\
\hline X3.2 & 0,485 & 0,2759 & Valid \\
\hline X3.3 & 0,425 & 0,2759 & Valid \\
\hline X3.4 & 0,557 & 0,2759 & Valid \\
\hline X3.5 & 0,618 & 0,2759 & Valid \\
\hline X3.6 & 0,738 & 0,2759 & Valid \\
\hline X3.7 & 0,542 & 0,2759 & Valid \\
\hline X3.8 & 0,386 & 0,2759 & Valid \\
\hline X3.9 & 0,651 & 0,2759 & Valid \\
\hline X3.10 & 0,679 & 0,2759 & Valid \\
\hline X3.11 & 0,562 & 0,2759 & Valid \\
\hline X3.12 & 0,635 & 0,2759 & Valid \\
\hline X3.13 & 0,549 & 0,2759 & Valid \\
\hline X3.14 & 0,768 & 0,2759 & Valid \\
\hline & & &
\end{tabular}

Tabel 4. Hasil Uji Validitas Y Kinerja Karyawan

\begin{tabular}{cccc} 
No. & $\boldsymbol{r}_{\text {hitung }}$ & $\boldsymbol{r}_{\text {tabel }}$ & Ket \\
\hline Y.1 & 0,420 & 0,2759 & Valid \\
\hline Y.2 & 0,514 & 0,2759 & Valid \\
\hline Y.3 & 0,376 & 0,2759 & Valid \\
\hline Y.4 & 0,675 & 0,2759 & Valid \\
\hline Y.5 & 0,407 & 0,2759 & Valid \\
\hline Y.6 & 0,534 & 0,2759 & Valid
\end{tabular}

Uji Reliabilitas (keandalan) yaitu ukuran suatu kestabilan dan konsistensi responden dalam menjawab hal yang berkaitan dengan kontruk-kontruk pertanyaan yang merupakan dimensi suatu variabel dan disusun dalam suatu bentuk kuesioner (Sujarweni, 2015). Keandalan (reliability) menunjukkan sejauh mana pengukuran tersebut tanpa bias (bebas kesalahan - error free) dan karena itu menjamin pengukuran yang konsisten lintas waktu dan lintas beragam item dalam instrumen (Sekaran, 2014). Jika nilai Cronach Alpha $>0,60$ maka variabel dianggap reliabel. Hasil penghitungan dapat disajikan pada tabel sebagai berikut: 
Tabel 5. Hasil Uji Reliabilitas

\begin{tabular}{lccc} 
Variabel & Cronbach $\alpha$ & $r_{\text {tabel }}$ & Ket \\
\hline $\mathrm{X} 1$ & 0,863 & 0,60 & Reliabel \\
\hline $\mathrm{X} 2$ & 0,857 & 0,60 & Reliabel \\
\hline $\mathrm{X} 3$ & 0,881 & 0,60 & Reliabel \\
\hline $\mathrm{Y}$ & 0,730 & 0,60 & Reliabel \\
\hline
\end{tabular}

Data yang diperoleh menunjukkan bahwa setiap instrumen dan variabel yang digunakan valid dan reliabel untuk digunakan dalam penelitian ini.

\section{Uji Normalitas}

Data yang berdistribusi normal artinya data yang mempunyai sebaran yang normal, dengan profil yang dapat dikatakan bisa mewakili populasi (Sujarweni, 2015).

$$
\text { Histogram }
$$

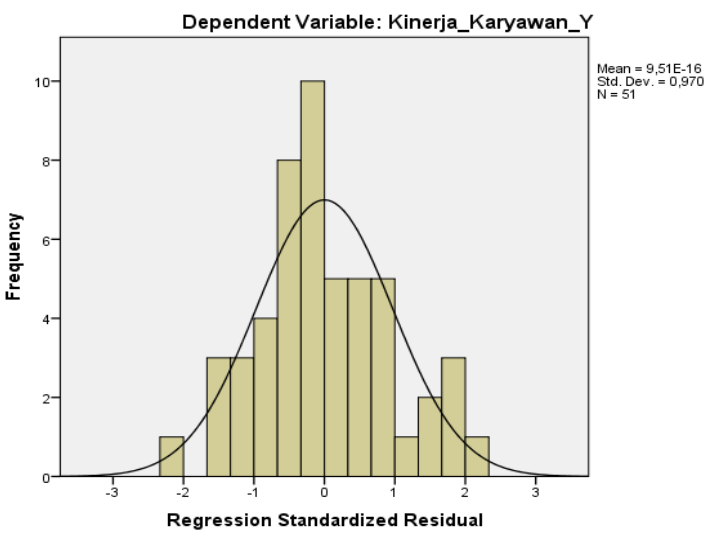

Gambar 2. Histogram Uji Normalitas

Gambar 2 menunjukkan dari hasil uji normalitas berdasarkan histogram menunjukkan bahwa variabel berdistribusi normal dan layak digunakan untuk memprediksi kinerja karyawan karena histogram yang dihasilkan membentuk lonceng dengan garis yang tidak condong ke kiri ataupun ke kanan.

\section{Hasil Uji F (Uji Simultan)}

Berikut merupakan hasil Uji $\mathrm{F}$ Anova dari variabel motivasi, insentif, dan budaya organisasi terhadap variabel kinerja karyawan.

Tabel 8. Hasil Uji F

ANOVA

\begin{tabular}{ccc}
\hline Model & F & Sig. \\
& & \\
\hline 1 Regression & 34,765 & 0,000 \\
\hline
\end{tabular}

Tabel 8 berdasarakan hasil Uji $F$ menunjukkan bahwa variabel bebas yaitu motivasi, insentif dan budaya organisasi secara simultan berpengaruh signifikan terhadap variabel kinerja karyawan operator produksi PT IKP disebabkan nilai $F_{\text {hitung }}=34,765>F_{\text {tabel }}=$ 2,800 atau nilai probabilitas uji $\mathrm{F} 0,000<\alpha=$ 0,05 .

\section{Hasil Uji t (Uji Parsial)}

Untuk menentukan $\mathrm{H}_{0}$ ataupun $\mathrm{H}_{1}$ yang ditolak atau diterima dapat dilakukan dengan membandingkan $t_{\text {hitung }}$ setiap variabel dengan $t_{\text {tabel }}$ pada tarap nyata $5 \%(\alpha=0,05)$ yaitu 2,012 .

Tabel 9. Hasil Uji t Coefficients

\begin{tabular}{llrr}
\hline Model & t & Sig. \\
\hline $\mathbf{1}$ & (Constant) & $-0,185$ & 0,854 \\
\hline \multicolumn{2}{c}{ Motivasi_X1 } & 2,224 & 0,031 \\
\hline \multicolumn{2}{c}{ Insentif_X2 } & 1,066 & 0,292 \\
\hline \multicolumn{2}{r}{ Budaya_Organisasi_X3 } & 5,010 & 0,000 \\
\hline \multicolumn{2}{r}{ Dependent Variable: Kinerja_Karyawan_Y }
\end{tabular}

Hasil uji t dengan membandingkan nilai $t_{\text {hitung }}$ dengan $t_{\text {tabel }}$ dapat dijelaskan bahwa secara parsial motivasi berpengaruh signifikan terhadap kinerja karyawan operator PT IKP karena $t_{\text {hitung }}(2,224)>t_{\text {tabel }}(2,012)$ atau nilai probabilitas uji t 0,031< $\alpha=0,05$, begitu pula untuk variabel budaya organisasi berpengaruh signifikan terhadap kinerja karyawan operator PT IKP karena $t_{\text {hitung }}(5,010)>t_{\text {tabel }}(2,012)$ atau nilai probabilitas uji t $0,000<\alpha=0,05$. Adapun 
untuk variabel insentif secara parsial tidak berpengaruh signifikan terhadap kinerja karyawan operator PT IKP karena $t_{\text {hitung }}(1,066)$ $<t_{\text {tabel }}(2,012)$ dan nilai probabilitas uji $t$ bernilai 0,292 $>\alpha=0,05$.

\section{Hasil Koefisien Determinasi $\left(\mathbf{R}^{\mathbf{2}}\right)$}

Berikut ini merupakan hasil dari koefisien determinasi model.

Tabel 10. Koefisien Determinasi Model Summary

\begin{tabular}{lllll}
\hline Model & $\mathbf{R}$ & $\begin{array}{l}\mathbf{R} \\
\text { Square }\end{array}$ & $\begin{array}{l}\text { Adjusted } \\
\mathbf{R} \text { Square }\end{array}$ & $\begin{array}{l}\text { Std. } \\
\text { Error of } \\
\text { the } \\
\text { Estimate }\end{array}$ \\
\hline $\mathbf{1}$ & 0,830 & 0,689 & 0,670 & 1,421 \\
\hline
\end{tabular}

Tabel 10 menunjukkan hasil perhitungan Adjusted $R$ Square sebesar 0,670 yang berarti variabel bebas yaitu motivasi, insentif dan budaya organisasi dapat menjelaskan variabel terikat yaitu kinerja karyawan sebesar $67 \%$ sedangkan sisanya sebesar 33\% dijelaskan oleh variabel lain yang tidak diuji dalam penelitian ini.

\section{Pembahasan}

Berdasarkan latar belakang dalam penelitian ini, masih ditemukan kendala terkait total produksi yang rata-rata di tahun 2017 kurang dari target. Hasil yang penelitian menunjukkan bahwa variabel motivasi dan budaya organisasi memiliki pengaruh yang positif dan signifikan terhadap kinerja karyawan operator PT IKP-Bogor, sedangkan variabel insentif tidak memberi pengaruh signifikan terhadap kinerja karyawan operator PT IKP-Bogor. Kemungkinan penyebab variabel insentif tidak memberi pengaruh terhadap kinerja karyawan operator PT IKP, karena karyawan merasa sudah cukup terpenuhi kebutuhan baik material maupun nonmaterialnya meskipun tidak diberikan insentif tambahan dari perusahaan. Hal yang ditemukan saat dilakukannya penelitian justru karyawan khususnya bagian operator produksi lebih membutuhkan perhatian dari pihak perusahaan dalam bentuk komunikasi dua arah yang baik, adanya kontrol yang berkesinambungan dari setiap penerapan kebijakan, hubungan antara atasan dan bawahan yang lebih hangat dan pemberian motivasi kepada karyawan secara personal.

Selain itu melihat dominannya pengaruh budaya organisasi terhadap kinerja karyawan, maka perusahaan juga perlu menciptakan kebijakan yang dapat mewakili harapan karyawan tanpa mengurangi identitas dan citra baik perusahaan serta bersifat fleksibel dan transparan agar suasana yang tercipta menjadi lebih harmonis sehingga karyawan tidak merasa adanya aturan yang merugikan dan terkesan memaksakan kehendak perusahaan semata.

Hasil persamaan regresi pada variabel insentif menunjukkan angka positif sehingga ketika insentif meningkat maka akan terjadi peningkatan pada kinerja karyawan. Hal ini berarti meskipun insentif tidak memberi pengaruh yang signifikan terhadap kinerja karyawan dalam kondisi tertentu, namun perhatian perusahaan terhadap karyawan melalui pemberian insentif tetap dapat membantu meningkatkan kinerja karyawan. Diperkuat pula oleh tingginya nilai signifikansi pada uji simultan, berarti ketika motivasi, insentif dan budaya organisasi secara bersamaan ditingkatkan oleh perusahaan maka kinerja karyawan akan meningkat secara signifikan. Hal ini mendukung penelitian sebelumnya yang dilakukan oleh tha dan Widarto (2015), juga penelitian yang dilakukan sebelumnya oleh Maria,Magdalena, dan Leonardo (2016).

Berdasarkan uraian pembahasan ini, dapat dikatakan bahwa insentif yang diberikan perusahaan kepada karyawan operator produksi tidak selalu menstimulasi kinerja karyawan. Ada kondisi tertentu ketika karyawan lebih memerlukan pemberian motivasi yang tinggi serta budaya organisasi yang hangat dan berorientasi pada karyawan 
untuk menstimulasi kinerja karyawan. Oleh karena itu perusahaan di bidang usaha manufaktur, khususnya PT IKP-Bogor perlu memperhatikan dan menganalisis hal ini dengan baik.

\section{PENUTUP}

Berdasarkkan hasil penelitian dan pengujian hipoteis yang dilakukan dengan menggunakan analisis regresi berganda dapat disimpulkan bahwa secara simultan variabel motivasi, insentif dan budaya organisasi berpengaruh secara signifikan terhadap kinerja karyawan operator PT IKP. Adapun secara parsial, variabel yang berpengaruh terhadap kinerja karyawan adalah motivasi dan budaya organisasi, sedangkan variabel insentif tidak berpengaruh signifikan terhadap kinerja karyawan operator PT IKP.

Adapun implikasi hasil penelitian ini terhadap perusahaan ialah, perusahaan sebaiknya lebih memperhatikan berbagai hal yang dapat memotivasi karyawan untuk bekerja maksimal dan menciptakan budaya organisasi yang berorientasi pada karyawan, seperti membuka forum diskusi secara berkala untuk mendengar ide, saran, keluh kesah yang dirasakan karyawan selama menjalankan tugasnya; perusahaan sebaiknya juga mempertahankan program-program serta kebijakan yang sudah menjadi citra dan identitas baik untuk perusahaan seperti pengawasan yang berkesinambungan atas beberapa kebijakan yang diberikan untuk kesesesuaian harapan karyawan terhadap perusahaan, adapun masukan terakhir adalah perusahaan harus tetap mempertahankan program-program insentif yang sudah diberikan kepada karyawan, seperti insentif kehadiran, bonus tahunan dan penghargaan masa kerja.

Saran untuk peneliti selanjutnya ialah penambahan variabel lain yang dapat mempengaruhi hasil kinerja karyawan pada suatu perusahaan seperti kompensasi, pelatihan, gaya kepempinan dan variabelvariabel lainnya.

\section{REFERENSI}

Badriyah, M. (2017). Manajemen Sumber Daya Manusia. Cetakan Kedua. Bandung: CV Pustaka Setia.

Bangun, W. (2012). Manajemen Sumber Daya Manusia. Jakarta: Penerbit Erlangga.

Destiana, S., dkk. (2015). Pengaruh Pemberian Insentif, Motivasi Kerja, dan Budaya Organisasi terhadap Kinerja Karyawan. Jurnal IImu Administrasi Bisnis, 4(2).

Fatimah, F. N. D. (2017). Panduan Praktis Evaluasi Kinerja Karyawan. Cetakan Pertama. Yogyakarta: Quadrant.

Gardjito, H, A., dkk. (2014). Pengaruh Motivasi Kerja dan Lingkugan Kerja terhadap Kinerja Karyawan. Jurnal Administrasi Bisnis, 13(1), 1-8.

Hanggraeni, D. (2012). Manajemen Sumber Daya Manusia. Cetakan Pertaman. Jakarta: Lembaga Penerbit Fakultas Ekonomi UI.

Hatta, I.H., dan Rachbini, W. (2018). Budaya Organisasi, Insentif, Kepuasan Kerja, dan Kinerja Karyawan.Jakarta.

Haedar, M. I., dan Gunair. (2015). Pengaruh Pemberian Insentif terhadap Kinerja Karyawan PT.Suraco Jaya Abadi Motor di Masamba Kabupaten Luwu Utara. Jurnal Equilibrium, 5(1), 15-21. DOI: http://dx.doi.org/10.35906/je001.v5i1.1 28.

Hutomo M., W, dkk. (2015). Pengaruh Budaya Organisasi dan Motivasi Kerja terhadap Kinerja karyawan.Surabaya. Agora, 3(2), 60-69.

Maziah. (2017). Pengaruh Pemberian Insentif Terhadap Kinerja karyawan PT BNI Syariah Makassar. Laa Maisyir Jurnal Ekonomi Islam, 4(2), 59-73. DOI: https://doi.org/10.24252/lamaisyir.v4i2. 4421.

Mustofa, G. (2017). Pengaruh Insentif Terhadap Kinerja Karyawan dengan Motivasi sebagai Variabel Moderasi. Malang. Jurnal Manajemen Bisnis, 7(2), 139-148. 
DOI: https://doi.org/10.22219/jmb.v7i2. 7008.

Nurani. (2015). Pengaruh Pemberian Insentif terhadap Kinerja Karyawan CV Logam Indonesia di Tulungagung. Benefit Jurnal Manajemen \& Akuntansi, 2(1), 1-18.

Nouziransyah, N. (2017). Pengaruh Budaya Organisasi terhadap Kinerja Karyawan. Jumantik (Jurnal Ilmiah Penelitian Kesehatan), 2(1), 13-25. DOI: http://dx.doi.org/10.30829/jumantik.v2i 1.961.

Robbins, S.P., dan M. Coulter. (2016). Manajemen. Edisi Ketiga Belas. Jilid I. Jakarta: Penerbit Erlangga.

Sedarmayanti. (2016). Manajemen Sumber Daya manusia Reformasi Birokrasi dan Manajemen Pegawai Negeri Sipil. Cetakan Kelima. Edisi Revisi. Bandung: PT Refika Aditama.

Sekaran, U. (2014). Research Methods for Business - Metodologi Penelitian Untuk Bisnis. Edisi Keempat. Jakarta: Penerbit Salemba Empat.

Siagian, S. P. (2015). Manajemen Sumber Daya Manusia. Cetakan Kedua Puluh Tiga. Jakarta: Bumi Aksara.
Sugiyono. (2015). Metode Penelitian Kuantitatif, Kualitatif dan R\&D. Cetakan Kedua Puluh Dua. Bandung: Penerbit Alfabeta

__ (2017). Sistematika untuk Penelitian. Cetakan Kedua Puluh Delapan. Bandung: Penerbit Alfabeta.

Sujarweni, V., W. (2015). SPSS untuk Penelitian. Yogyakarta: Penerbit Pustaka Baru Press.

(2015). Metodologi Penelitian Bisnis \& Ekonomi. Cetakan Pertama. Yogyakarta: Penerbit Pustaka Baru Press.

Theodora, O. (2015). Pengaruh Motivasi Kerja Terhadap Kinerja Karyawan. Jurnal Manajemen Bisnis Agora, 3(2), 187-194.

Wardani, K, R., dkk. (2016). Pengaruh Budaya Organisasi Terhadap Kinerja Karyawan. Jurnal Administrasi Bisnis, 31(1), 58-65.

Zainal, V. R., dkk. (2015). Manajemen Sumber Daya Manusia untuk Perusahaan: dari Teori ke Praktik. Cetakan Ketujuh. Jakarta: Rajawali Pers. 
